\title{
Membership density and trade union power
}

\section{Colin Crouch}

External Scientific Member, Max Planck Institute for the Study of Societies,

Cologne, Germany

Emeritus Professor, University of Warwick, Coventry, UK

\section{Article by an MPIfG researcher}

Colin Crouch: Membership Density and Trade Union Power. In: Transfer 23(1), 47-61 (2017). Sage Publications

The original publication is available at the publisher's web site: https://doi.org/10.1177/1024258916673533

\section{Summary}

Union membership has declined in almost all European and other advanced economies, though in many cases the membership that remains reflects overall changes in the gender and occupational structure of the economy. Meanwhile, in most countries unions' incorporation in governing institutions of the labour market has remained stable or risen. Union strength (membership density and incorporation) and to a lesser extent bargaining coordination correlate positively with core employee interests in the post-Keynesian economy: a combination of high employment and low inequality, and a balance between flexibility and security. The evidence suggests that unions' most important role today is as part of wider political forces, where the role of membership strength remains ambiguous.

\section{Résumé}

Les effectifs des syndicats ont reculé dans pratiquement tous les pays européens et dans les autres économies développées, même si, dans de nombreux cas, l'évolution des effectifs reflète les changements globaux de la structure du genre et de l'emploi au sein de l'économie. D'autre part, dans la plupart de ces pays, le rôle des syndicats dans les institutions qui régissent le marché du travail est demeuré stable, ou s'est renforcé. La puissance des syndicats (en termes de taux de syndicalisation et de rôle) et, dans une moindre mesure, la coordination de la négociation collective présentent une corrélation positive avec les intérêts essentiels des salariés dans l'économie post-keynésienne : la conjonction d'un taux d'emploi élevé et d'un faible niveau d'inégalité, et l'équilibre entre flexibilité et sécurité. Les éléments relevés suggèrent que le rôle plus important joué par les syndicats à l'heure actuelle s'inscrit dans le contexte de forces politiques de plus grande ampleur, alors que l'impact de l'importance des effectifs demeure ambigu.

\section{Zusammenfassung}

Die Gewerkschaften haben in fast allen europäischen und anderen Ländern mit entwickelten Volkswirtschaften Mitglieder verloren, wobei in vielen Fällen die noch verbliebene Mitgliedschaft ein Abbild der allgemeinen Veränderungen in der Gender- und Berufsstruktur dieser Volkswirtschaften

\section{Corresponding author:}

Colin Crouch, Max Planck Institute for the Study of Societies, 50676 Köln, Germany.

Email: colincrouch@me.com 
ist. In den meisten Ländern ist die Einbeziehung der Gewerkschaften in die Institutionen, die den Arbeitsmarkt regulieren, stabil geblieben oder intensiver geworden. Die gewerkschaftliche Stärke (Gewerkschaftsdichte und Einbindung) und zu einem geringeren Grad auch die Koordinierung von Tarifverhandlungen korrelieren positiv mit den Kerninteressen der Arbeitnehmer in der post-keynesianischen Wirtschaft: einer Kombination aus hohem Beschäftigungsniveau und geringer Ungleichheit sowie einem Gleichgewicht zwischen Flexibilität und Sicherheit. Die gewonnenen Erkenntnisse legen nahe, dass die wichtigste Aufgabe der Gewerkschaften heute darin besteht, sich als Teil größerer politischer Machtstrukturen zu verstehen, wobei der Stellenwert der Mitgliederstärke unklar bleibt.

\section{Keywords}

Union membership, union incorporation, union power, employment, inequality, flexicurity

Does the fact that trade union membership has declined in almost all advanced countries affect unions' ability to represent the interests they seek to serve? This question cannot be answered until we can define those interests and what is meant by serving them. This has long been a controversial issue, unions and their observers differing over whether they represent an entire working population or class, or just a membership, and over whether they would best represent that class through collaboration with employers, participation in conflictual cooperation, or outright opposition. The relevance of membership strength, of the structure of bargaining systems, and of unions' incorporation in labour market governance and public policy vary according to how these issues are resolved. The relative salience of these approaches has also varied with changing economic contexts. It will be contended here that in the present context of a neoliberal globalising economy unions' success in representing workers can be best assessed by their association with a combination of high levels of employment and relatively low levels of inequality. The most important finding from the research is that, however it is assessed, union strength is most closely associated with combining high employment and low inequality through an indirect influence on public policy rather than collective bargaining as such. This would seem to support what is defined here as the social democratic approach to unionism, though membership decline raises major questions about the sustainability of this model.

Attention will concentrate on Member States of the European Union (at the time of writing including the United Kingdom), together with Norway and Switzerland, but with some reference to developments in the industrialised Anglophone countries outside Europe, and in Japan, Russia and Turkey.

\section{The dimensions of union decline}

Thanks to the collection of data on trade unions, employment relations and other relevant issues coordinated by Jelle Visser at the Amsterdams Instituut voor Arbeidsstudies, known as the ICTWSS database (Visser, 2015), we know a good deal about unions in a large number of countries for much of the period since the end of the Second World War. This demonstrates that, in most of the then 'western' world, union membership, which had stagnated in the 1950s and earlier 1960s, saw major growth during the period of intensified industrial unrest and high inflation that began around 1968. Varying from country to country, this growth continued into the 1980 s and even the 
1990s. Then began the decline that has affected all countries except Belgium and, to some extent, Spain. In most cases the decline has been gentle; in others (for example Germany) it has been rapid.

A different logic has been at work in Central and Eastern Europe (CEE). Artificial unions with more or less compulsory membership characterised all state socialist economies. Despite their relationship to the communist states, these unions had often played some part in the protests that led to the downfall of the regimes at the end of the 1980s, and carried on their role in the new systems of capitalist democracy. However, their initially high memberships collapsed very rapidly, a process that even affected Poland, where the anti-regime union Solidarnośc had played the principal role in opposing the communist state. Unions had enjoyed more autonomy in the distinctive socialist economy of Yugoslavia, where there was significant worker participation in management. The violent civil wars that destroyed that country after 1990 led to much institutional destruction, except in Slovenia and Croatia, which are now members of the EU. Union membership has significantly held up better in these two countries than in the rest of Central and Eastern Europe, though in Slovenia at least it has begun to decline heavily in very recent years.

In some cases union members now (2014) count for less than half the proportion of the workforce that they did at the peak. In the west, where the peak was usually the $1980 \mathrm{~s}$, this is the case for Austria (declining from 67 per cent to 27 per cent), France ( 20 per cent to 8 per cent), Germany (33 per cent to 18 per cent), and the UK (50 per cent to 26 per cent). In CEE the decline, though much heavier, dates only from the early 1990s: Bulgaria (from 66 per cent to 17 per cent), Czech Republic (64 per cent to 13 per cent), Estonia (66 per cent to 7 per cent), Hungary ( 83 per cent to 11 per cent), Latvia ( 46 per cent to 13 per cent), Lithuania ( 31 per cent to 9 per cent), Slovakia (67 per cent to 13 per cent) and Slovenia (67 per cent to 13 per cent). Outside Europe there is similar evidence of decline: since the 1980s Australian membership has declined from 49 per cent to 17 per cent, that in Japan from 35 per cent to 18 per cent, New Zealand from 59 per cent to 19 per cent, and in the USA from 23 per cent to 11 per cent. In Russia the immediate post-Soviet unions had 67 per cent of the workforce; today they have 13 per cent.

These statistics all refer to union members as a proportion of total number of employees, the usual basis used to calculate union density. However, this understates the size of the total workforce that might be relevant. In some economies (most notably Greece and some other countries of southern Europe) self-employment is very high and in some sectors constitutes a workforce that is very difficult to organise, but which might compete for jobs and earnings with employed workers. This is also the case in countries such as the UK, where employers are insisting on giving their workers self-employed status in order to avoid legal obligations to employees. Also, in much of CEE and southern Europe large numbers of people work in the 'shadow economy', not included in the calculations but very often undermining negotiated rates of pay and working conditions. Self-employment has grown in several economies in recent years; whether the shadow economy has grown is more difficult to determine. However, it is certainly the case that unions everywhere represent smaller proportions of the total workforce than the normal density statistics suggest (see Figure 1).

The same decline has not applied, however, to unions' incorporation in institutions of labour market governance at a variety of levels from European and national policy-making to companylevel mechanisms. The ICTWSS show stability over the years on this dimension, with if anything some increase as EU directives took effect in central European countries and those like the UK which under national legislation had weak levels on these variables. This raises the important question whether formal incorporation compensates for membership decline or whether that decline undermines the effectiveness of incorporation. This leads in turn to the more fundamental question of unions' aims. 


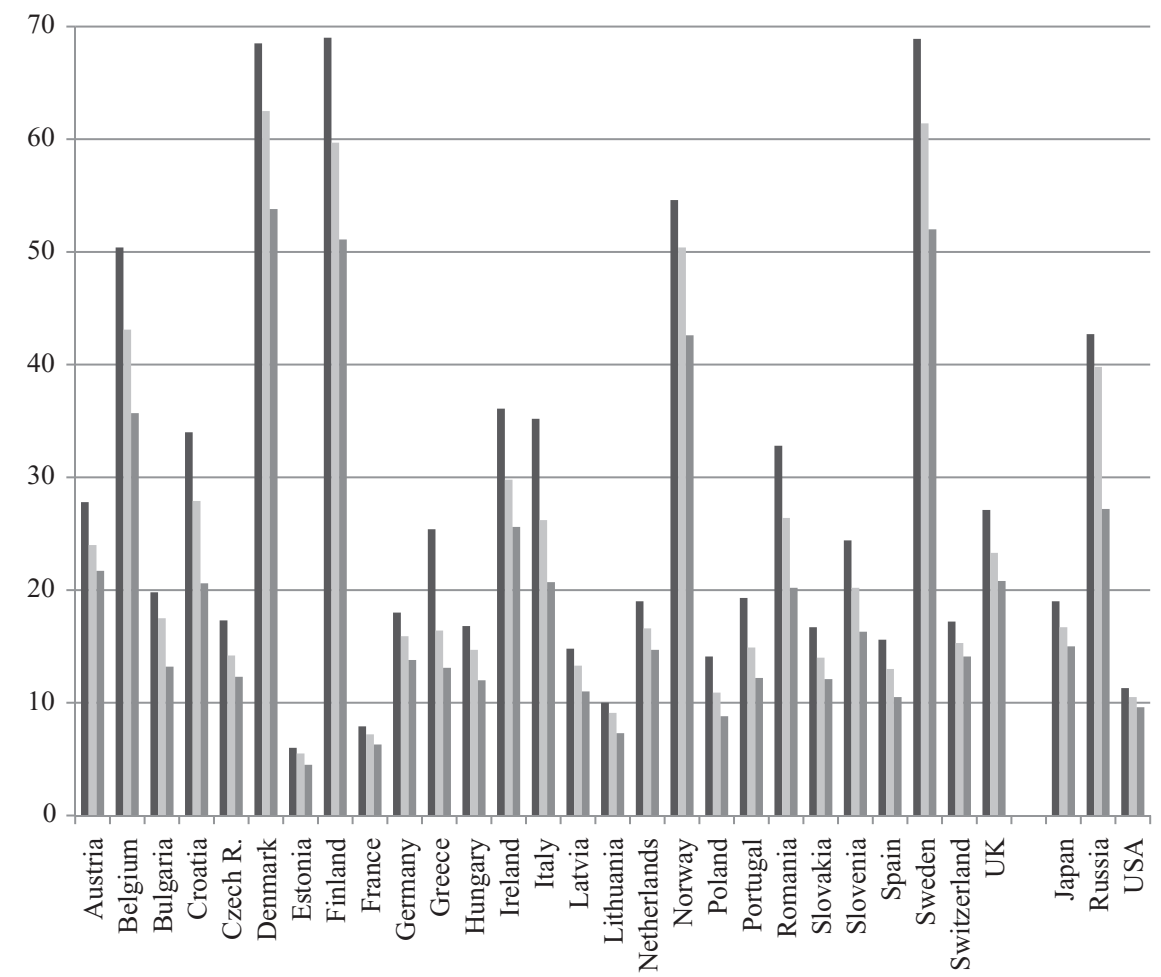

Figure I. Union membership as a proportion of: (i) legal, dependent employees; (ii) all legally employed workers; (iii) all workers, c. $201 \mathrm{I}$.

Sources: Union membership: Visser, 2015; self-employment: OECD, 2013 and Eurostat (website); shadow economy: Schneider and Buehn, 2012 and Schneider et al., 2010. Data for the following countries are for 2008: Bulgaria, Estonia, Hungary, Latvia, Romania, Russia.

\section{The meaning of union power}

Unions have potentially many goals, but an important contribution to simplification has been made by Hyman's (2001) distinction between activities oriented to market, class, and society. The first refers to collective bargaining for primarily monetary gains for workers, preferably union members, in a defined labour market position; the second to a broader agenda of prosecuting the interests of a working class through conflict; the third also has a wider perspective than specific labour markets, but aims at the peaceful integration of workers' interests through collaborative institutions within a harmonious wider society.

These differences have considerable resonance with the diversity of union histories. The market model of unions' role was important in early union history, particularly in the United Kingdom in the 19th century, but it developed particularly strongly during the Cold War years as so-called 'business unionism'. This was seen as inspired by the US model, where unions eschewed wider political goals and concentrated on winning wage increases for their members. This represented an alternative strategy for some European union leaders seeking an alternative to the class focus of communist unions, which had become embroiled in the international confrontation with the Soviet Union. Since employers would almost never accept collective agreements that applied only to union members, business unionism presented unions with a collective action problem, which they 
often solved with 'closed shop' arrangements for compulsory union membership. This model places considerable importance on membership strength, as it is that strength and its potential strike threat that induces employers to recognise unions and be willing to bargain. But strength across the economy as a whole is not important, only in those sectors or firms where unions are active. The model does not have a wider social agenda, so an individual union is not interested in what is going on in the rest of the economy - unless unions' weakness in some sectors starts to attract investment away from sectors where they are strong. Incorporation in labour market governance is by the same token also of low importance for this model, apart from the necessary acceptance by employers of collective bargaining institutions.

However, this model was never pure and its dominance in the early post-war decades when many US unions were strong did not survive their massive decline. US unions never avoided politics, being involved in promoting public policies across a wide range of domestic and foreign policy issues and in sponsoring candidates for public office. This gave them elements of a class and society orientation, but they never resolved the implications of this for membership and incorporation before business unionism itself came under major attack. The fragmented bargaining that the model implied was unable to avoid contributing to the inflationary spiral that characterised much of the post-war period until the 1980s. The consequences can be seen even more clearly in the fate of British unions, which, though they followed even less than their US counterparts the idea of being apolitical, constituted a primary example of fragmented bargaining from an initial position of union strength. If unions concentrated mainly on seeking localised wage increases within an economy where they accounted for a minority of the workforce, all they could achieve were gains for unionised firms and sectors at the expense of the rest of the working population. Where governments were following Keynesian policies and more or less guaranteeing male full employment, this meant inflation and often consequent hostility to unions among non-unionised workers - though also a rise in union membership in order to come under their protection. Once governments turned to monetarist and other neoliberal policies from the 1980s onwards, ceasing to support the idea of closed shops, and more important no longer guaranteeing male full employment, the consequences of fragmented bargaining became unemployment or at best defensive concessional bargaining. Business unionism ceased to be an enviable model.

The class model of unionism has been highly important in theory and ideology and in the motivation of many activists, though in practice it has rarely been able to achieve its goals and has had to be content with achievements more closely identified with the other two models. It was seen most clearly in countries where communist parties and unions were strong - though not in those cases where communist parties formed governments, where class conflict was deemed to be over and such a role for unions unnecessary. In these countries union membership was virtually compulsory, so membership levels were very high. There was also extensive incorporation of unions in labour market and public policy institutions, though in the absence of open debate it must be doubted how representative these were. Communist movements outside the state socialist countries took a different approach to membership. The most important cases were France and Italy, particularly the former. French unions long maintained that membership was less important than the ability of unions to mobilise workers to support them when necessary - for example, in obeying strike calls or in voting for union candidates in works council elections. From the communist perspective the purpose of works councils was not to achieve concrete goals, but to provide a rallying point for class demands that could not be met within the existing structure of class relations. Italian communist unions shared the French perspective until the 1970s, when mass membership grew and unions began to adopt other models of action. 
This approach flourished during the first part of the 20th century, but reached what may have been its final climax in the resurgence of unrest starting in the late 1960s. Since then strikes, its main indicator of success, have declined, though with occasional outbursts that defy the overall trend.

A society orientation among unions shares with the class perspective a wider concern than immediate bargaining, but it avoids conflict and seeks institutions that will incorporate the interests of workers within the institutions of existing society. Membership is therefore not so important as the existence of institutions that facilitate this incorporation. The main historical base for this model was Roman Catholic social policy, though there are isolated examples in various countries of individual firms that deploy various methods for consulting employees, though often without union membership. The model thrived temporarily in a general form under the fascist dictatorships of the inter-war years, where it was known as corporatism. Like the state socialist model, the overall undemocratic political form implied compulsory membership, a high level of formal incorporation, and severe doubts over real representativeness.

The forms of union activity that became dominant during the second half of the 20th century, particularly in Europe, were hybrids of these pure cases, best known as social democratic through association with the political parties linked to this kind of unionism. This was particularly important in north-west Europe, where there emerged a kind of compromise between the society and class orientation. This shared with the Marxist model a class-wide perspective and a political appreciation that bargaining for wage rises for limited groups of workers was an inadequate project. However, unlike the Marxists and more like the 'business' unions, social democratic unions were interested in what could be achieved within the existing capitalist economy. Their class orientation meant that they were not initially concerned with that economy's own problems of survival, but given at least their de facto acceptance of the capitalist order, ensuring its health became implicitly part of their agenda. Particularly in the small open economies of north-west Europe - and in Germany, whose extreme export dependence made it also highly open - unions were forced to accept that their wage demands must not price products out of international markets. This both required them to have regard for the impact of wage bargaining across the economy (taking them away from business unionism and a simple market focus) and to share something of the society model. Formal incorporation of unions in labour market governance and public policy was clearly important. The class perspective survived in their willingness to threaten conflict if necessary, and membership strength was deemed important for this.

As the other models declined the neocorporatist, social democratic one became that to which most European union leaders aspired. It has however its own vulnerabilities, in particular in the form of a double paradox. First, the main criterion for assessing the 'success' of union activity became the containment of wage costs (rather than maximising wages) and the avoidance of inflation. Many academic observers of industrial relations contended that when unions, employers' organisations and bargaining arrangements were centralised with open trading economies, they had capacity for strategy and, given that high inflation served nobody's interests, they would use that capacity to contain wage costs (e.g. Crouch, 1993). Therefore, second, the more that the organisation of collective bargaining departed from the free market in being coordinated and centralised, the more it would produce outcomes compatible with that market. A number of studies demonstrated this, culminating in the work of the late Franz Traxler, who showed that two organisational forms of collective bargaining were consistent with controlled inflation: centralised bargaining and key-sector or pattern bargaining, where a major export price-sensitive sector dominated bargaining outcomes across an economy (Traxler, 2003; Traxler and Brandl, 2010; Traxler and Kittel, 2000; Traxler et al., 2001; Traxler et al., 2008). 
It might be argued that, if the main result of strong unions and centralised or pattern bargaining was to contain the inflationary consequences that might otherwise flow from collective bargaining, would it not be better to have no bargaining and no trade unions at all? This became the dominant theme of the neoliberal critique of collective industrial relations, leading to a general strategy pursued by many governments and to some extent by the European Commission itself of trying to marginalise and disaggregate collective bargaining activity - to the achievement of which objective the general decline in union membership has contributed. But the social democratic model was not just about securing wage rises, which is just one of three forms of union action. A second is grievance handling for members in the workplace, and the pursuit of certain norms of managerial fairness and even treatment of different groups of workers. Third - and very differently from business unionism - unions form part of wider political movements seeking social and fiscal policies that reduce inequality and provide security for the lives of workers and their families.

This reasoning might resolve the paradoxes of what social democratic unions seek to achieve, but it creates another concerning the motivation of workers to join unions. Unions' role in grievance handling and offering advice to members is not problematic and might be enough to attract many workers without raising issues of the logic of collective action; but how many workers can be expected to join unions because they use wage bargaining to contain labour costs, even if that contributes to avoiding inflation? Even more, when we reach the level of general social policy, the links between an individual's action in joining a union and some eventual national or European policy outcomes are remote indeed. Not surprisingly, most research on union membership has concluded that workers are not motivated to join by expectation of calculable individual gains, but by seeing themselves as part of a general culture, of which union membership is a part. But this kind of motivation clearly declined as the highly collective environments of manufacturing and mining, with their historic memories of major class conflict in earlier decades, declined as forms of employment. The diversity of work activities and organisational forms of many post-industrial services sectors do not provide such an environment. The main exceptions are those occupations that require extensive training and a professional identity, with the consequence that union strength is increasingly found among non-manual professional workers. But do these identities relate to a general culture producing distinctive sets of social policies, as in the social democratic model, or do they lead further towards business unionism or the protection of privileged groups? This is where the issue of membership strength becomes really serious.

\section{The changing focus of social democratic union priorities}

The decline of Keynesian policies and of inflation disturbed the social democratic model. Once governments ceased to try to guarantee full employment through fiscal and monetary policy, unions faced the challenge that successful bargaining for higher wages would produce, not inflation, but unemployment. This pressure was intensified by globalisation and firms' growing ability to locate certain activities in countries and regions with low wages. Sustaining and improving employment levels has become what Léonard (2001) has called the 'new general equivalent'. Again, as with inflation, economists could argue that the complete absence of unions and collective bargaining would best ensure low unemployment. How could social democratic unionism find a renewed raison d'être in such a context?

There are two potential answers to this fundamental question. First, when labour markets are left to clear themselves, they do so by depressing wages at the lower levels of the workforce and increasing inequality. When many sectors are dominated by oligopolies operating in a global economy, there will be a growth in the rewards of senior managers, which further increases 
inequality. It might be claimed that where unions are active and powerful, these pressures will be reduced. This would happen, partly through the egalitarian tendencies of collective bargaining itself, and partly through the operation of general fiscal and social policies in societies where unions are politically strong. Second, in addition to egalitarian pressure, we should expect unions to work for public policies that assist workers in coping with a difficult employment environment through measures that do not threaten the level of employment itself.

From these arguments we can derive two hypotheses to submit to empirical test. Where unions are strong and strategically effective:

1. High levels of employment are more likely to be combined with lower levels of inequality, and

2. Policies that combine labour market flexibility with measures to support workers' security will be more prominent, than where they are weak.

This implies a change from the focus on whether strong unions could be combined with low inflation that characterised earlier neo-corporatist research. The hypotheses now need to be operationalised and tested.

Two indicators of union strength have been used in the present discussion: the idea with which we began, membership density; and one that has emerged in the discussion of the social democratic model: degree of incorporation in labour market governance. We can also test separately the measure of collective bargaining strategic effectiveness, defined as the product of bargaining coverage and union centralisation (bargaining coordination). These are our independent variables. The dependent variables for hypothesis 1 are: the level of employment, the level of inequality (measured by the Gini coefficient), and the combination of these two. The last offers the best test of the hypothesis. For hypothesis 2, a recent study by economists at the European Commission (2013) enables us to assess different national performances on various indicators of so-called 'flexicurity', though only for full Member States of the EU. Attention will be concentrated on the most recent years for which data are available, usually 2012 or 2013 . The hypotheses will be tested through a series of simple regressions. The number of cases is too small to use more complex regression analysis combining larger numbers of variables. An approach often taken in this kind of research with small numbers of cases is to use annual data over a run of years. This is not a sound approach to use here, as institutional variables change only slowly and do not operate on the basis of annual variations that might be expected to produce an immediate effect on outcomes.

The overall results of the correlation tests are shown in Table 1.

\section{Unions, employment and inequality}

Looking first at the employment variable alone, there are only very weak correlations with the indicators of union strength, though that with union incorporation is moderately strong. Correlations with the main measure of inequality (the Gini coefficient) are stronger, especially that with union incorporation. The overall result is consistent with the finding of OECD research that the decline of coordinated bargaining had been one of the causes of the recent rise in inequality (2011), though the OECD did not, however, emphasise the role of incorporation.

Hypothesis 1 concerns the optimisation of employment and low inequality, not the achievement of either alone. The combined index multiplies the employment level by the reciprocal of the Gini coefficient, where that coefficient ranges between 0.00 and 1.00. (Calculations have used the reciprocal of the Gini scores, so that positive correlations indicate higher levels of equality.) All 
Table I. Correlations $\left(r^{2}\right)$ between measures of union strength and economic and social policy outcomes, European countries, 2012/2013.

\begin{tabular}{|c|c|c|c|c|}
\hline & $\begin{array}{l}\text { Union } \\
\text { density }\end{array}$ & $\begin{array}{c}\text { Union } \\
\text { incorporation }\end{array}$ & $\begin{array}{l}\text { Density and } \\
\text { incorporation }\end{array}$ & $\begin{array}{l}\text { Bargaining } \\
\text { coordination }\end{array}$ \\
\hline \multicolumn{5}{|l|}{ Employment and inequality } \\
\hline Employment (2013) & 0.09377 & 0.24328 & 0.16435 & 0.07364 \\
\hline Gini $(2013)$ & 0.24931 & 0.3914 & 0.3335 & 0.23947 \\
\hline Combined employment and Gini (20I3) & 0.20386 & 0.40956 & 0.31298 & 0.17777 \\
\hline \multicolumn{5}{|l|}{ Flexicurity indicators* } \\
\hline Availability of flexitime (2004) & 0.49346 & 0.53769 & 0.62773 & 0.52584 \\
\hline $\begin{array}{l}\text { Population aged } 25-64 \text { participating in education } \\
\text { or training }(20 \mathrm{II})\end{array}$ & 0.4834 & 0.33364 & 0.5374 & 0.34003 \\
\hline Long-term unemployment (20II) & 0.2868 & 0.24602 & 0.33158 & 0.20863 \\
\hline 5-year replacement rate $(2010)$ & 0.35517 & 0.22112 & 0.10231 & 0.22301 \\
\hline Family responsibilities (20I0) & 0.1104 & 0.16856 & 0.17584 & 0.12178 \\
\hline
\end{tabular}

* Data cover EU Member States only.

four independent variables again correlate positively with the combined index, though only incorporation shows a slight rise over the correlation with low inequality alone. Hypothesis 1 is not refuted: strong systems of collective industrial relations are positively if modestly associated with optimal combinations of high employment and low inequality. It is however striking that the strongest of the independent variables is neither the structure of the collective bargaining system nor union strength as measured by density, but the presence of unions in formal representational institutions.

Figure 2 enables us to examine which countries conform to the hypothesis and which refute it, using the strongest relationship we have found, that between the overall strength of union incorporation and the combined index measuring employment and equality. Taking as a measure of non-conformity having a score that diverges by more than one standard deviation from that which would be predicted by the equation of the straight line, the Czech Republic, Switzerland and the UK perform better than might be expected given their incorporation scores, and constitute failures of the hypothesis. Performing worse than expected are three of the southern European debtor economies, Greece, Italy and Spain. These 'over-conform' with, rather than refute, the hypothesis.

All non-European cases for which we have data have incorporation scores well below the European mean. In line with hypothesis 1, Russia and the US also have low combined employment and equality scores compatible with this, Turkey extremely so. However, Australia, Canada and Japan defy the hypothesis, performing better than their incorporation score would imply.

\section{Unions and flexicurity}

Flexicurity is a concept that has been much abused in the policy literature, with a tendency for observers to treat social policies designed to confront the so-called 'old social risks', such as support during times of unemployment, disability and sickness as, at best, playing no part in modern concepts of security, and, at worst, actually undermining them in their idea of security pursued through flexibility (Burroni and Keune, 2011; Crouch and Keune, 2012). However, a recent study by the European Commission (2013) examines national performances against a rich and fully developed interpretation of flexicurity that is fully compatible with hypothesis 2 . Full 


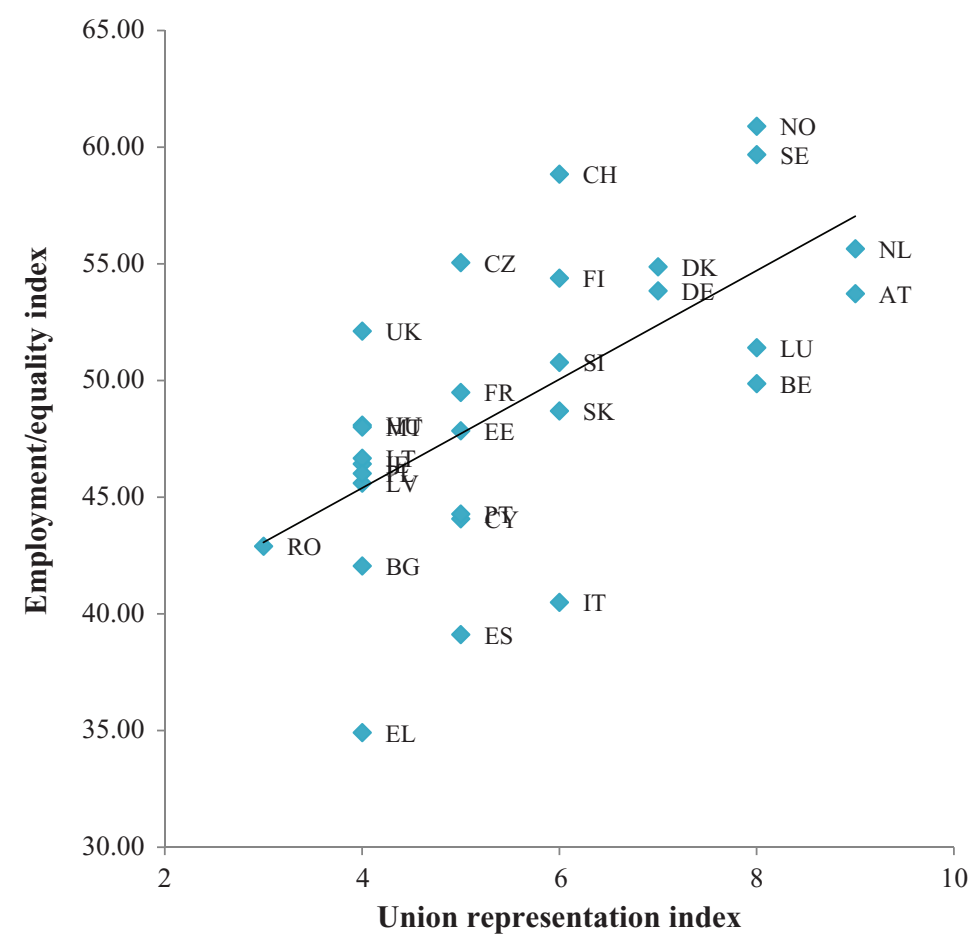

Figure 2. Union representation by combined index of employment and equality, c. 2013.

appreciation was also shown of the role of social partners in sustaining flexicurity arrangements. The report, which concentrated on EU Member States only and therefore excluded Norway and Switzerland, as well as Croatia, which has joined the EU only recently, explored four different components of flexicurity, looking at both change since before the years of crisis (i.e. since 2000) and at the most recent years for which data are available (usually 2010 or 2011):

1. flexible and reliable contractual arrangements;

2. availability of lifelong learning;

3. effective labour market policies;

4. a modern social security system, this variable being subdivided into two separate parts:

(a) social protection;

(b) reconciliation of work and family life.

The key findings of this research have been related to the union and employment relations variables considered above by Crouch (2016b), on which the following discussion draws heavily. The main results are summarised in Table 1. Nine separate indicators were found for component 1 , flexible and reliable contractual arrangements. Only one country, Sweden, had above-mean scores on all indicators across the period studied, though Austria, Denmark and the Netherlands were close behind. These are all countries with particularly strong levels of social partnership, including two of the three Nordic cases for which data were available (i.e. not Finland). Overall, however, there was no statistical relationship with any of the three employment relations variables. This is not surprising, as the proportion of persons with the same employment security as the previous year 
is an outcome variable rather than one measuring policy output. In other words, it looks at the situation on the labour market and not just at the results of policy change. This is the right approach for assessing what is actually happening to workers on the ground, but since it will be shaped by many factors affecting economies, it is less likely to relate clearly to any variables concerning employment relations arrangements. However, if we turn to the indicator for this component most amenable to action by bargaining - the availability to workers of flexitime - we find strong positive relationships with the employment relations variables, especially for the combined measure of union density and incorporation. It should be noted that the flexitime data relate to 2004, before the crisis.

For component 2, availability of lifelong learning, the report gathered data on seven indicators. Again Sweden was overall the highest scoring country in 2011, followed by Denmark, the Netherlands and Luxembourg. The weakest scores were in certain central European countries (Bulgaria, Hungary, Latvia, Poland, Romania, Slovakia), but also France and Italy. The authors took as the key indicator the percentage of the population aged 25 to 64 participating in education or training. This correlated moderately strongly and positively with all employment variables, with the combined density and incorporation measure being again the strongest.

Four indicators were used for component 3, effective labour market policies, the key one being the rate of long-term unemployment of the active population. Scoring above the European mean across the range were Denmark, Belgium, France and Germany. Sweden, Finland and the Netherlands performed reasonably well across most indicators. Consistently below mean were Italy and a number of central European cases (the Baltic states, Bulgaria, Hungary, Slovakia). The key indicator correlated moderately and negatively, with combined union density and incorporation being the most important, suggesting at least that there is no basis for assuming that union strength and strong social partnership are associated with poor employment performance.

The researchers used eight measures for component $4 \mathrm{a}$, social protection, the poverty risk of the unemployed aged over 18 (proportion of unemployed living below 60 per cent median equalised income after social transfers) being taken as key. Few overall patterns emerged. Spain was a strong performer on all components except for the unemployment trap; the UK was the opposite. Germany had by far the worst performance for the key indicator of the poverty impact of unemployment. There was no correlation with employment relations variables for this indicator where so many other factors than policy involving social partners might be involved. Slightly stronger relationships are found when we examine one of the policy-related variables, the replacement rate of unemployment compensation after five years without work. This correlated modestly, the strongest being for union density.

Finally, component $4 \mathrm{~b}$, reconciliation of work and family life, was measured through various child-care policy variables. A combination of inactivity and part-time work due to personal and family responsibilities was taken as the key negative outcome indicator. The two best performing countries overall were the Netherlands and Luxembourg, and on the key indicator the Netherlands, Sweden, Denmark, Slovakia and Austria. The worst were Romania, Latvia, Germany and Greece. There were however only very modest correlations overall with the employment relations variables.

Overall there is support for hypothesis 2 on at least some of the variables. There were general statistical relationships between employment relations variables and certain flexicurity indicators (availability of flexitime, adult participation in education and training, and, to a lesser extent, reduced long-term employment). Combined union membership strength and union incorporation was for all these issues the most important variable. The Nordic countries and the Netherlands continue to outperform the rest of Europe on a strong interpretation of flexicurity. The only other 
countries to come close to them on a number of components were Austria, Luxembourg and, to a lesser extent, Germany. These have also been countries with strong records of social partnership, particularly Austria. No country with low or indifferent scores for social partnership featured at all consistently on the measures of flexicurity. Denmark, Sweden and the Netherlands had strong relative scores on all components of the flexicurity model. Finland was less consistent.

There are signs of a weakening of the flexicurity model in its heartland, as has been anticipated by observers (Due and Madsen, 2008). Denmark may have performed strongly on all components, but on four of them the European Commission research (2013) showed that it had particularly high levels of relative deterioration: contract flexibility, ALMP, social protection and family flexibility - all issues where the country has been a world leader. Sweden's position was less dramatic, though the generosity of its social protection had declined. Finland was both poor in performance and declining on contract flexibility. Austria, which remained strong on this indicator, was nevertheless also declining in its performance on it. However, both Austria and Finland were strengthening their relative performance on lifelong learning and generosity of social protection. Germany had seen a dramatic decline in its ability to keep the long-term unemployed out of poverty, though it had also seen a considerable decline in those at risk of being long-term unemployed.

The institutional variables within which flexicurity is nested - strong, incorporated unions and coordinated collective bargaining - are moving in different directions, with the former stable or even rising, the latter declining. The countries and forms of employment relations originally associated with various forms of flexicurity continue to be its most important exemplars, and have continued with relatively successful economic and employment performance throughout the crisis period; but on several indicators they have been declining in relative terms, and usually this has been within the context of absolute decline across Europe. There are also disturbing signs of a failing reach of the inclusiveness of coordinated bargaining, especially where young workers are concerned.

\section{Conclusions}

From the 1960 s to the 1980 s the central narrative about organised employment relations in most western European countries was that a strong and growing trade union movement could both serve workers' interests and be compatible with a stable, non-inflationary economy, provided collective bargaining was centrally coordinated on both the employers' and employees' sides, the arrangements that were known as neo-corporatist. From the 1990s onwards this narrative has been collapsing. Union membership has been declining almost everywhere; the arrival of genuine unions in Central and Eastern Europe, which at first seemed to bring new points of union strength has in fact done the opposite. Inflation has declined as the principal economic issue, and Keynesian demand management has declined (though not disappeared) as the major toolkit of economic policy. As a result, inflation has been replaced by a struggle to sustain employment levels as a key priority for workers and unions. Consistently with this, several governments, employers and eventually the European Commission have sought to undermine coordinated collective bargaining. Its work in controlling inflation seems to be no longer needed.

While inflation has become a minor issue in the post-Keynesian economy, it has been replaced by increasing worker insecurity, as male full employment can no longer be regarded as guaranteed, while old forms of job protection have become outmoded. There is also strong evidence that such an economy is accompanied by growing inequality. However, the evidence produced in this article suggests that strong employment relations institutions can play a role in moderating these problems for workers' lives. The associations are only moderately strong, but it appears that strong, 
incorporated unions and coordinated bargaining are associated with optimal combinations of high employment and lower inequality, and with positive combinations of flexibility and security. There is certainly no support for rival neoliberal hypotheses, which must suggest that such institutions would be associated with negative outcomes. Only a small number of countries, mainly the Czech Republic, suggest that high unemployment and low inequality can be combined with weak industrial relations institutions.

Of course, employment relations institutions are by no means the only factors that will have produced different outcomes in different countries. In particular it is notable that the three bestperforming countries on many variables (Denmark, Norway, Sweden) are outside the European Monetary Union, while Finland, which shares their labour market institutions but is part of EMU, performed less well. It is however not the case that all EMU members performed poorly and all non-members well, and one lacks a counter-factual for how all EMU members might have performed had they retained their currencies.

It is doubtful if any conclusions can be drawn from the fact that combined membership density and union incorporation tend to be strongest for the flexicurity variables and incorporation alone for the employment/inequality ones, as the sample of countries is slightly different (i.e. no Croatia, Norway or Switzerland in the former case). More robust and interesting is the consistent finding that union density and/or incorporation are more important than bargaining coordination. The latter had been the key variable in earlier studies of the counter-inflationary role of neo-corporatist bargaining institutions, but not in the new climate where employment and flexicurity have become more important goals.

The relationship between coordinated bargaining and low inflation was fairly direct, as central bargainers with authority had a direct impact on wages and therefore prices. The link between employment relations institutions and the relationship between employment and inequality is more complex. This emerges further from a closer look at cross-national variations in inequality. One can examine income inequality before and after the impact of taxation and transfers. The former shows the operation of the labour market, the latter the impact of political action on that market's outcomes. Data comparing the two have been made available by the OECD. This means that we lose the poorer east European countries, but can include Europe's neighbours (Russia and Turkey) and the two main non-European industrial powers (Japan and the USA). There is virtually no relationship between union strength (density and incorporation) and the pre-tax and transfer Gini score $\left(\mathrm{r}^{2}=0.0544\right)$, but when taxes and transfers are included the correlation increases considerably to $r^{2}=0.3349$ (for further details, see Crouch 2016a: 165-167). Three of the non-European cases (Russia, Turkey and the USA) have even more inequality than we would expect on the basis of their low union strength; three CEE countries (the Czech and Slovak Republics and Slovenia) have considerably less. Japan fits the pattern of most European cases.

If union strength had its main impact on collective bargaining, we should expect the main relationship between it and inequality to take place pre-tax, but this is not the case. The evidence suggests that unions' wider connections with egalitarian political parties and movements are more important than their immediate bargaining. Or does the explanation run the other way: are unions better able to flourish where the power of the wealthy is reduced? Or are both the level of inequality and union power the results of further contextual factors about the societies concerned, such as the past political power of labour movement parties, or general social values about the acceptability of inequalities of power and income at work? Low inequality and union power seem to engage in mutual reinforcement. Employment relations variables may well be proxies for something more important that we cannot easily assess: an overall importance within society for employee interests, expressed perhaps partly through the role of unions, partly through that of 
parties associated with them, partly through general cultural differences across societies over the importance that needs to be given to working people. If this is the case, perhaps unions' mass membership is less important than their incorporation in institutions that sustain those cultures.

If so, should we expect those achieved positions to continue indefinitely, proof against membership decline and against change in the general culture of what is now a post-industrial workforce? Will it be enough for the demographic profile of union members to adjust to changes in the workforce despite overall decline? Or will this erosion eventually lead interests that do not share a concern for combining low inequality with high employment or security with flexibility to take an opportunity to challenge the positions that, in at least some countries, organised labour achieved in a different economy and society?

If combining low inequality with a high level of employment is the main feasible objective of contemporary trade unions, the compromise between a society and a class focus embedded in the social democratic union model clearly remains viable. The narrow focus of business unionism is unable to cope with these broad variables, while any unions still following a simple society model will be less interested in the reduction of inequality. Advocates of the class model might reasonably claim that the membership and incorporation strength necessary to the social democratic model is fragmenting, though their ability to provide evidence of a rise in class conflict increasingly depends on local, largely defensive movements (Hyman, 2015).

\section{Funding}

The author received no financial support for the research, authorship, and/or publication of this article.

\section{References}

Burroni L and Keune M (2011) Flexicurity: a conceptual critique. European Journal of Industrial Relations 17(1): 75-91.

Crouch C (1993) Industrial Relations and European State Traditions. Oxford: Oxford University Press.

Crouch C (2016a) Society and Social Change in 21st Century Europe. London: Palgrave Macmillan.

Crouch C (2016b) Flexicurity and the Crisis. In: Larsen TP and Ilsøe A (eds) The Danish bargaining modelinside out. Copenhagen: Djøf.

Crouch C and Keune M (2012) The governance of economic uncertainty: beyond the 'new social risks' analysis. In: Bonoli G and Natali D (eds) The Politics of the New Welfare States. Oxford: Oxford University Press, pp. 45-67.

Due J and Madsen JS (2008) The Danish Model of Industrial Relations: Erosion or Renewal? The Journal of Industrial Relations 50(3): 513-529.

European Commission (2013) Flexicurity in Europe. Administrative Agreement JRC N³1962-2010-11 NFP ISP - FLEXICURITY 2 Final Report. Luxembourg: Office for Official Publications of the European Communities.

Eurostat website Eurostat Statistics Database. Available at: http://www.bing.com/search? $\mathrm{q}=$ European + Commission $+(2013)+$ Flexicurity + in + Europe + Administrative + Agreement $+\mathrm{JRC}+\mathrm{N}$ $\% \mathrm{C} 2 \%$ B03 1962-2010-11+NFP+ISP+-+FLEXICURITY+2+Final+Report.\&src=IE-SearchBox $\&$ FORM $=$ IESR02

Hyman R (2001) Understanding European Unionism: between market, class and society. London: SAGE. Hyman R (2015) Three scenarios for industrial relations in Europe. International Labour Review 154(1): $5-14$.

Léonard E (2001) Industrial Relations and the Regulation of Employment in Europe. European Journal of Industrial Relations 7(1): 27-47. 
OECD (2011) Divided We Stand: Why Inequality Keeps Rising. Paris: OECD.

OECD (2013) OECD Factbook 2013. Paris: OECD.

Schneider F and Buehn A (2012) Shadow economies in highly developed OECD countries: what are the driving forces? IZA Discussion paper 6891. Bonn: IZA.

Schneider F, Buehn A and Montenegro CE (2010) Shadow economies all over the world. Policy Research Working Paper 5356, World Bank Developing Economics Group. Washington DC: World Bank.

Traxler F (2003) Bargaining (De)centralization, Macroeconomic Performance and Control over the Employment Relationship. British Journal of Industrial Relations 41(1): 1-27.

Traxler F and Brandl B (2010) Collective Bargaining, Macroeconomic Performance, and the Sectoral Composition of Trade Unions. Industrial Relations 49(1): 91-115.

Traxler F and Kittel B (2000) The bargaining system and performance: A Comparison of 18 OECD countries. Comparative Political Studies 33(9): 1154-1190.

Traxler F, Blaschke S and Kittel B (2001) National Labour Relations in Industrialized Markets. Oxford: Oxford University Press.

Traxler F, Brandl B and Glassner V (2008) Pattern Bargaining: An Investigation into its Agency, causes Context and Evidence, British Journal of Industrial Relations 46(1): 33-58.

Visser J (2015) The ICTWSS Database 5.0 2015. Amsterdam: AIAS. 